\title{
Changes in pastoralist commons management and their implications in Karamoja (Uganda)
}

\author{
Zuzana Filipová ${ }^{1}$ \\ Nadia Johanisova \\ Masaryk University, Czech Republic
}

\begin{abstract}
This article analyzes the progression from traditional to current pastoralist practices and the contemporary diversification of livelihoods of the Jie group of the Karimojong in the Kotido district in Karamoja (Uganda). the focus is on changes of land use, framed by the commons debate. We identify factors that have forced the Karimojong to abandon their traditional mobile pastoral lifestyle and to adopt new income-generating activities, including charcoal production and brick-making, which may have detrimental effects on local forest and soil cover. These have included repeated enclosure of common grazing lands by colonial and postcolonial governments. We conducted empirical research (interviews and focus group discussions) in 2012. They confirm the superiority of traditional pastoralist practices (in terms of safeguarding sustained productivity of pastures) compared to the current situation. An important factor leading to current unsustainable pastoralist practice involved the mass acquisition of firearms by the Karimojong in the 1970s and 1980s, violent cattle raiding and subsequent unequal disarmament and establishment of army-controlled cattle herding. This radical enclosure of the commons by the government, linked to impoverishment of a large part of the population in terms of cattle numbers, has necessitated the emergence of new, potentially environmentally detrimental livelihoods for the Jie. However, the escalation of the firearm crisis cannot be seen in isolation from a century of commons enclosure by governments, curtailing traditional practices and leading to insecurity and impoverishment of the Karimojong. The situation is exacerbated by current policies of the Ugandan government, geared to agricultural sedentarization, which may be unsustainable given the local natural and climatic conditions.
\end{abstract}

Key Words: Pastoralism, Karamoja, environmental degradation, commons, political ecology, colonialism

\section{Résumé}

Cet article analyse la progression des pratiques traditionnelles à la diversification contemporaine des moyens de subsistance du groupe Jie du Karimojong dans le district de Kotido à Karamoja (Ouganda). L'accent est mis sur les changements d'utilisation des terres, encadrés par le débat sur les communes. Nous identifions les facteurs qui ont obligé Karimojong à abandonner leur mode de vie pastoral mobile traditionnel et à adopter de nouvelles activités génératrices de revenus, y compris la production de charbon de bois et la fabrication de briques, ce qui peut avoir des effets néfastes sur les forêts et les sols locaux. Ces facteurs ont inclus l'enclos répété des pâturages communs par les gouvernements colonial et post-colonial. Nous avons mené des recherches empiriques (entretiens et discussions en groupes de discussion) en 2012. Les résultats confirment la supériorité des pratiques pastorales traditionnelles (en termes de sauvegarde de la productivité durable des pâturages) par rapport à la situation actuelle. Un facteur important qui a mené à une pratique pastorale insoutenable actuelle a été l'acquisition à grande échelle d'armes à feu par les Karimojong dans les années 1970 et 1980, des raids de bétail violents et un désarmement inégal subséquent et l'établissement d'un élevage de bovins contrôlés par l'armée. Cette enceinte des communes par le gouvernement, liée à l'appauvrissement d'une grande partie de la population en termes de nombre de bovins, a nécessité l'émergence de nouveaux moyens de subsistance pour le Jie, potentiellement nuisibles sur le plan environnemental. Cependant, l'escalade de la crise de l'arme à feu ne peut être considérée isolément d'un siècle d'enceinte commune par les

\footnotetext{
${ }^{1}$ Zuzana Filipová, former student at Masaryk University, Czech Republic. Email: zuz.filipova "at" gmail.com. Dr. Nadia Johanisova, Assistant Professor, Faculty of Social Studies, Masaryk University, Brno, Czech Republic. Email: nadiaj "at" volny.cz. Work on this article was supported by Grant No. GA 14-330945 of the Grant Agency of the Czech Republic. ZF lived in Karamoja from October 2011 to September 2012.
} 
gouvernements, ce qui réduit les pratiques traditionnelles et conduit à l'insécurité et à l'appauvrissement du Karimojong. La situation est exacerbée par les politiques actuelles du gouvernement ougandais, axées sur la sédentarisation agricole, qui peuvent être insoutenables compte tenu des conditions naturelles et climatiques locales.

Mots clés: Pastoralisme, Karamoja, dégradation de l'environnement, biens communs, écologie politique, colonialisme

\section{Resumen}

Centrándose en los cambios de uso del suelo, y enmarcado en el debate sobre los comunes, el presente artículo analiza la evolución de las prácticas pastoriles tradicionales hasta la actualidad, así como la diversificación contemporánea de los medios de vida, del grupo Jie de los Karimonjong, en el distrito de Kotido, Karamoja (Uganda). El artículo identifica algunos de los factores que han obligado a los Karimonjong a abandonar su estilo de vida pastoril nómada tradicional en favor de nuevas actividades generadoras de ingresos, tales como la producción de carbón vegetal y ladrillo, que pueden haber tenido un efecto negativo sobre los bosques y la cobertura del suelo local. Estos factores incluyen la restricción reiterada de los pastos comunales por parte de los gobiernos coloniales y post-coloniales. Los resultados de nuestro estudio empírico, basado en entrevistas y talleres de discusión realizadas en 2012, confirman la superioridad de las prácticas pastoriles tradicionales, en relación con la salvaguarda de la productividad sostenible de los pastos, respecto a la situación actual. Tal y como nuestra investigación indica, la insostenibilidad de las prácticas pastoriles actuales se encuentra fuertemente vinculada con la abundante adquisición de armas de fuego por parte de los Karimojong en las décadas de los 70 y 80, así como a los subsecuentes asaltos al ganado, desarme desigual y establecimiento de rebaños vigilados por el ejército. Este final y radical Esta restricción radical de los comunes por parte del gobierno, relacionada con el empobrecimiento de gran parte de la población en cuanto a la posesión de ganado, ha tenido como consecuencia el surgimiento, dentro de la comunidad de los Jie, de nuevos medios de subsistencia con un impacto medioambiental potencialmente negativo. Sin embargo, nuestra investigación indica que no es posible desvincular el agravamiento de la crisis armada, del siglo de imposiciones gubernamentales restringiendo los comunes, limitando las prácticas tradicionales y provocando la inseguridad y el empobrecimiento de los Karimojong. La situación se ve exacerbada por las políticas actuales del gobierno de Uganda orientadas hacia una sedenterización agraria que, dadas las condiciones naturales y climáticas de la región, podría ser insostenible.

Palabras claves: Pastoralismo, Karamoja, degradación ambiental, comunes, política ecológica, colonialismo

\section{Riassunto}

Concentrandosi sui cambiamenti nell'uso del suolo e prendendo in considerazione il dibattito sulle aree comuni di pascolo, il presente articolo analizza l'evoluzione delle pratiche pastorali tradizionali fino ai recenti cambiamenti e la diversificazione contemporanea dei mezzi di sostentamento nel gruppo dei Jie, appartenenti ai Karimojong, nel distretto di Kotido (Uganda). Nel presente articolo si idenitifcano i fattori che hanno obbligato i Karimojong ad abbandonare il loro stile di vita pastorale tradizionale in favore di nuove attività generatrici di reddito che includono la produzione di carbone vegetale e mattoni, le quali possono avere un effetto negativo sulle foreste locali e sulla copertura del suolo. Questi fattori includono la ripetuta restrizione delle aree di pascolo comuni da parte dei governi coloniali e post-coloniali. I risultati di questo studio empirico, basato su interviste e discussioni di gruppo realizzate nel 2012, conferma la superiorità delle pratiche pastorali tradizionali rispetto alla situazione attuale in relazione alla salvaguardia di una produttività sostenibile dei pascoli. Come si evince dalla ricerca, alcuni fattori importanti che hanno condotto all'attuale insostenibilità delle pratiche pastorali derivano dalla consistente acquisizione di armi da fuoco da parte dei Karimojong negli anni 70 e 80, dai furti di bestiame, dal conseguente disarmo avvenuto in maniera diseguale e dall'allevamento del bestiame controllato dall'esercito. Questa restrizione radicale delle terre pastorali da parte del governo, associata alla diminuzione del numero dei capi di bestiame e al conseguente impoverimento della popolazione, ha determinato la creazione di nuovi sistemi di sussistenza per i Jie, potenzialmente dannosi per l'ambiente. Ciò nonostante, la presente ricerca indica che l'intensificazione della crisi delle armi non può essere isolata dalle conseguenze di piú di un secolo di restrizioni delle aree di pascolo perpetuate dei governi che hanno limitato le pratiche tradizionali e hanno provocato insicurezza e inpoverimento dei Karimojong. La situazione è aggravata dalle attuali politiche del governo Ugandese 
orientate alla sedentarizzazione agricola dei Karimojong che potrebbe essere insostenibile considerando le condizioni naturali e climatiche della regione.

Parole chiave: Pastoralismo, Karamoja, degradazione ambientale, terre comuni, ecologia politica, colonialismo

\section{Introduction}

Common property management is an enduring theme in the social sciences, and debates continue about the merits of communal and privatized tenure. Although in the global North communal tenure is mostly considered ineffective and old-fashioned (Bollier 2010) or appears forgotten (Agrawal 2002: 42), in the global South it is very much alive and widespread. Hardin's critique of the commons has been widely criticized (Deb 2009; Feeny et al. 1990; Ostrom et al. 2006; Marshall 2005), but his rationale based on a well-worn Homo economicus model, where utility is invariably maximized at the expense of others, is still being used to legitimize further enclosure of existing commons today (Harvey 2007). At the same time, struggles against commons enclosure continue. These struggles are persistent because disruption to commons management systems tends to have far-reaching impacts on lives and livelihoods, and on the environment.

In the context of the global South, many factors that disrupt traditional lifestyles are linked to the impacts of development policies and modernization pressures on traditional societies, or indeed whole countries (Rahnema 1998a: x). Land management of the commons has regularly been targeted for change brought about by development and modernization processes. The impacts, some of them unintentional, have been extensive, including environmental, social and economic changes to livelihoods and land management (Rahnema 1998b).

In the Karamoja region in northeast Uganda, the local pastoralist society has faced efforts at disruption and change to its traditional commons management and livelihoods since the British colonization of Uganda at the end of the $19^{\text {th }}$ century (Dyson-Hudson 1966: 6-21). The traditional lifestyle of the Karimojong was affected by various factors, which have culminated in an inability to maintain traditional ways of life. In recent decades, this has led to adoption of new income-generating activities such as the sale of firewood and the making and sale of bricks and charcoal on a commercial basis to an increasing urban population requiring them for construction and fuel. ${ }^{2}$ Wood is used to fire the bricks, as well as for charcoal, with effects on land cover (Nalule 2010). A study by Nampindo et al. (2005: 32), based on aerial photography, indicates that the loss of woody cover ranged from $7 \%$ in Kotido district to $16 \%$ and $36 \%$ in Moroto and Nakapiripirit districts respectively between 1985 and 2002, but with positive change in some other areas (see Figure 1). ${ }^{3}$ Loss of woody cover leads to a decreased ability of the land to retain water, more runoff and more soil degradation. Brickmaking itself necessitates mining of the topsoil, further jeopardizing agricultural production in this agriculturally marginal region. In addition, despite a reduction in pastoralist livelihoods, Nalule (2010) encountered disturbing indications of heavy grazing, leading to biodiversity loss, soil compaction and soil erosion.

The Karamoja region is one of the most underdeveloped in Uganda. Local inhabitants face challenges such as environmental degradation, droughts, erratic rains, food insecurity as well as ethnic marginalization by government, affecting the provision of services. A lack of appropriate educational and health systems and poor infrastructure further contribute to high poverty rankings for the region. ${ }^{4}$ From the 1980 s until the

\footnotetext{
${ }^{2}$ The production and sale of bricks and charcoal is conducted at a local level, i.e. within the Karamoja region, rather than exported. Nevertheless these are still commercial rather than subsistence activities, and the bricks and charcoal are sold in urban centers, with negative environmental consequences for the rural hinterland.

${ }^{3}$ However, it is important to note that neither study links loss of forest cover in the region unequivocally to charcoal and brick production.

${ }^{4}$ Two poverty-mapping studies conducted in 1992 and 1999 indicated that the Northern region of Uganda (including Karamoja, then subsumed under two districts out of a total of nine districts in the region) had the highest rates of poverty in the country. In 1992, within the Northern region itself, the two Karamoja districts had the second and third highest rates of the population below poverty line (approximately $87 \%$ and $91 \%$ ). The Northern region within Uganda and the
} 
present, it has been the target of wide-ranging humanitarian and development aid, due to chronic food insecurity. The World Food Programme has been providing assistance in Karamoja since 1963 (WFP 2016) and a number of international NGOs and agencies have established field offices in Karamoja. ${ }^{5}$

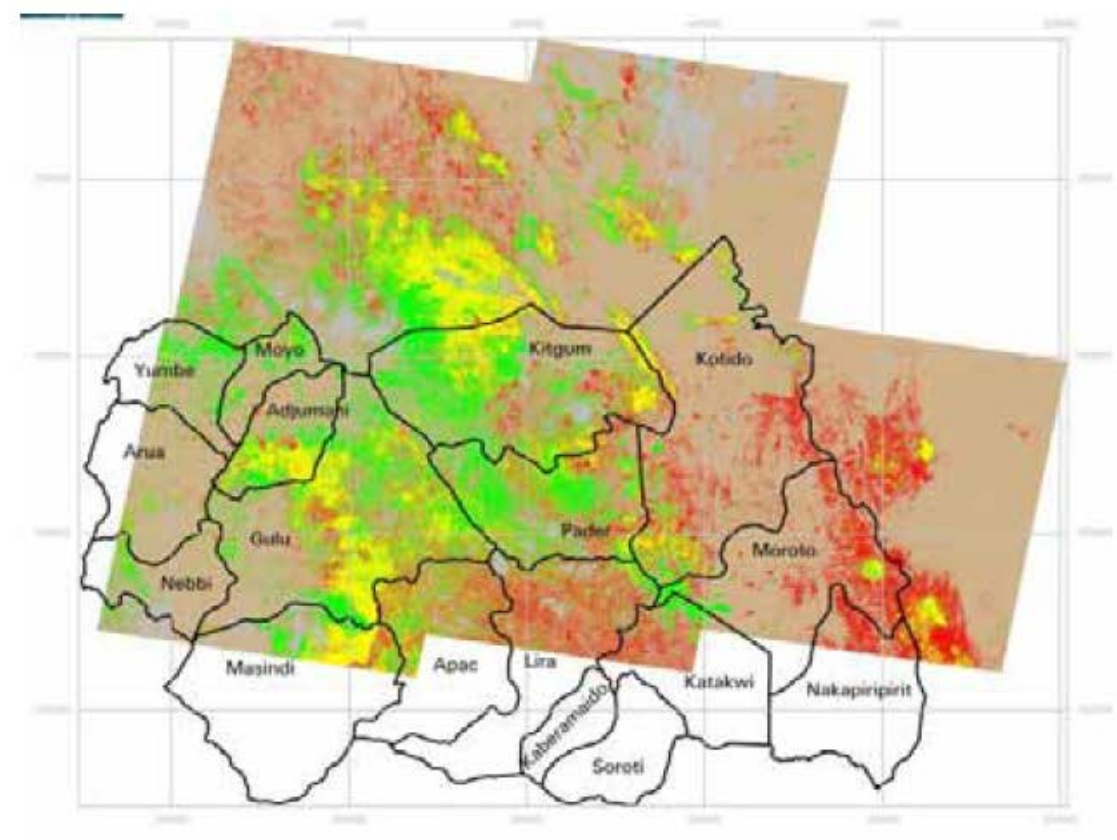

Woody Cover Change Classes Increased Woody Cowar Unchanged Woody Cover Decressed Woody Cover Other [L Cloud / Cloud Shadow

Figure 1: Loss of woody cover in Karamoja region between 1985 and 2002. Source: Nampindo et al. 2005: 31.

Data from the $\operatorname{KFSCS}^{6}$ team confirm that most of the households in Karamoja are currently dependent on income-generating activities other than pastoralism. Currently many Karimojong rely on markets for their survival. A study by the leading intergovernmental organization $\mathrm{IOM}^{7}$ states that natural resource extraction using wood for charcoal producion, topsoil to make bricks, and quarrying stone is a primary source of income for $40 \%$ of households in Karamoja, and a secondary source for an additional $20 \%$ (KFSCS 2010: 2-3). Livestock management, once dominant, is now a primary source of income only for $17 \%$ of households and a secondary source for $14 \%$. So approximately one third of the inhabitants of the region are still dependent on livestock (and approximately the same percentage practice agriculture and unskilled casual labor) (KFSCS 2010).

The aim of this article is to look at the links between the disruption to traditional commons management and the current livelihood practices of the Karimojong, which are often linked to environmental degradation in the region. More specifically, we try to identify the deeper causes behind the growth in unsustainable natural resource extraction and use. We focus on the unraveling of the traditional pastoralist

Karamoja districts within the Northern region remained at the top of the poverty statistics even in 1999 (Emwanu et al. 2003).

${ }^{5}$ These include UN FAO, UNICEF, ACF (Action Against Hunger), IRC (International Rescue Committee), DRC-DDG (Danish Refugee Council - Danish Demining group) and GIZ (German Cooperation agency) among others.

${ }^{6}$ Karamoja Food Security and Community Stabilization Programme.

${ }^{7}$ International Organization for Migration (www.iom.it). 
lifestyle, as an important cause of this shift in livelihood strategy. Our aim is to describe the traditional pastoralist way of life (with a special emphasis on its environmental dimensions) and the changes brought about from the colonial period onwards, as seen by the Karimojong and by other groups in the region. This is set within a broader analysis drawing on relevant regional literature and on post-development studies, ecological economics and political ecology. More generally, we wish to contribute to narratives that link overexploitation of natural resources by marginalized groups to wider political and economic pressures and interventions, fueled by power and modernist development efforts (Robbins 2012: 21; Spencer 1998).

To understand what led to changes in traditional commons management and the adoption of new livelihoods, we identified the following research questions:

- Was the traditional lifestyle environmentally sustainable?

- Were traditional institutions in place to protect the environment?

- Which factors influenced these traditional institutions?

- What influence did each factor have on the lifestyle of the Karimojong?

- How did the changes in lifestyle influence the environment?

Section Two explores the links between land tenure and environmental conservation, and discusses the rationalization of enclosure of the commons in the name of development and of the stemming of environmental decline. Sections Three and Four concentrate more specifically on a description of the Karamoja region and its pastoralist community and on commons enclosure in the region. After explaining its context and methodology (section Five), we present our results in three sections, with a particular focus on the sustainability of the traditional pastoral lifestyle of the Karimojong, on indigenous means of environmental conservation, and the factors of change in traditional natural resource management. In the discussion (Section Nine) we look at the deeper roots of environmental destruction in Karamoja beyond the scope of the empirical research presented, such as changes in pasture management during colonial rule and contemporary government policies. The conclusions (Section Eleven) summarize the data and arguments, and suggest a way forward for future research in the region.

\section{Enclosure of the commons in the name of development and environmental conservation}

How does land tenure determine a people's impact on the environment? This remains a contested topic. Guha and Martinez-Alier (2000: 12) use the term "ecosystem people" for groups who are fully and directly dependent on the natural environment they live in. Because ecosystem people are directly reliant on natural resources, they have developed many rules and strategies in order to conserve, preserve and protect their natural environment, and tend to use its resources sustainably. But as Gadgil and Guha (1995) show, it is easy to create ecosystem refugees, "foraging the scraps of civilization" (Spencer 1998: 219) following loss of access to their means of production.

Spencer (1998) describes the sophisticated and varied traditional survival strategies of pastoralists and agro-pastoralists such as the Karimojong in ecologically marginal (and thus fragile) ecosystems in Kenya, Tanzania, Uganda and Southern Ethiopia and Sudan, an intricate geography of livelihoods that he refers to as "the pastoral continuum." Institutionalized reciprocity and gifting of cattle exists among family clans, linked to marriage arrangements within tribes. Livelihoods demonstrate flexibility through access to differentiated and adequate grazing lands, owned and used in common (Spencer 1998: 209). ${ }^{8}$ Neville and Rada Dyson-

\footnotetext{
${ }^{8}$ In some areas and under some circumstances, pastoralism was complemented by cultivation (often the domain of women), trading and foraging. Another occasional element was predation: raids by young men on other tribes to secure livestock. In many of these East African groups, patriarchal social relations prevailed, with the women's role in food production trivialized (Spencer 1998: 19).
} 
Hudson also conducted a detailed meta-study of traditional East African pastoralist livelihood strategies in terms of energy use and nutrition, and concluded that their achievement was remarkable "in terms of their efficiency and suitability to the arid environments they inhabit" (Dyson- Hudson and Dyson-Hudson 1982: 228).

From a mainstream perspective, however, ecosystem people are generally not seen as conservationists, but rather as destroyers of the environment. Once this stereotype takes hold, the next logical step entails calls for development, growth and, often, privatization of the commons (Basset and Zuéli 2003: 115). The justification for commons enclosure is frequently enhanced efficiency and productivity. Private ownership of formerly communal land can be justified as liberating for peasant families and individuals, who are assumed to become new owners of formerly communal land and can then enter the market economy by selling it, improving it or using it as collateral for loans (de Soto 2001). As Lane (1994: 81) explains with direct reference to African pastoral areas, privatization is often promoted as a panacea, and especially as a contribution to increased effectiveness of common rangelands. From this point of view the absence of clearly defined ownership rights is considered to be an obstacle to the effectiveness, productivity and good management of natural resources (Jacobs 1991; de Soto 2001).

As traditional pastoralists often manage their land communally, they have been among those most affected by development and modernization policies (Rahnema 1998). Concurrent with this was the mainstream stigmatization of pastoralists as primitive, backward and irrational, dating from colonial times (Spencer 1998: 220). This led to the belief that such communities must be helped and assimilated into the majority society (Lane 1994). Commons enclosure often involved shifts from pastoralism to farming, or from extensive subsistence pastoralism to more intensive commercial ranching. In East Africa, disasters resulted. Spencer (1998: 221 - 222) describes problematic government projects in Kenya, where schemes in effect privatized the best grazing lands, leading not only to overgrazing, but to increasing wealth inequalities.

Traditional communal ownership has been viewed by suspicion not only by capitalist governments, but also by socialist Tanzania (as described by Spencer 1998: 221) as well as by communist governments including China. Huang et al. (2009), Squires and Youlin (2009) and Conte (2015: 81-82) describe how traditional pastoral societies in Inner Mongolia were gradually forced by the Chinese government to change their pasture management systems in order to meet national targets for increased production of livestock and animal feed. Sustainably managed pastures became highly degraded as a result of sedentarization, the privatization of land, an influx of newcomers, and conversion to agriculture on fragile soils.

Enclosure of the commons is often justified within the framework of environmental conservation itself, often invoking Hardin's "tragedy of the commons" (1968). Hardin argued that commoners actually behave as individualistic rational maximizers of their own personal utility (Zografos and Howarth 2010). They will put too many animals out to feed and thus cause overgrazing and erosion. The "tragedy" is that as the land becomes degraded, everybody loses, but privatization limits free-riding. This rationale led to promotion of commons enclosure. The assumption that humans are individualistic utility maximizers leads towards the commodification of natural resources and their consequent privatization or, in some cases, nationalization. The approach has roundly criticized (Daly and Farley 2004: 163; Gendron 2012: 69). Paul Spencer, while accepting Hardin's Malthusian argument in a general sense and interpreting it as a warning against unimpeded commercial exploitation of the Earth, implicitly rejects the assumption of East African pastoralists as specimens of homo economicus:

In the traditional setting, the resolution of the Tragedy of the Commons lies in the strength of community bonds, and such indigenous concepts as "marriageability", "trustworthiness" and "credibility" reflect the reputations of families and individuals on which their further collaboration depends. Institutions are based on trust. (Spencer 1998: 219) 
According to Bassett and Zuéli (2003: 123), who discuss the World Bank African development strategy model of the early 2000s, communal land tenure was still not given the prominence that it deserves in development agencies' guidelines. The World Bank model assumes interdependency between the mode of land tenure, resource conservation and agricultural and pastoral output. According to the model, communal land tenure is associated with low agricultural and pastoral output and inadequate resource conservation. On the other hand, individual land tenure is seen as bringing high agricultural and pastoral output as well as a high level of resource conservation (Basset, Zuéli 2003: 103). Such policy recommendations have been very influential. Traditional communal land tenure is not as a rule considered suitable for modern environmental planning and privatization is considered a legitimate means of preventing natural resource degradation (Bassett and Zuéli 2003; Scott 2004). Even though there have been revisions of the 1975 World Bank's Land reform policy paper and it is now recognized that some communal tenure systems can be more cost-effective than formal land titles, the guiding principles of the World Bank policy, promoting among others "owneroperated family farms" and the "need for markets to permit land to be transferred to more productive users", have in many ways remained unchanged (Binswanger and Deininger 1999: 247).

\section{Karamoja and the Karimojong: geographical and ethnic characteristics and traditional livelihood patterns}

The Karamoja region lies in northeastern Uganda bordering South Sudan to the north and Kenya to the east. The area covers $27,200 \mathrm{~km}^{2}$ and has seven districts. The Karimojong had 1.1 million citizens in 2001 according to the Census, 3\% of the national population, and numbers have risen since that time. The Karimojong people form a part of the Karamoja cluster. They share the same ethnic origin, language group and a similar pastoralist lifestyle, with the pastoral communities of Uganda, South Sudan, Ethiopia and Kenya (Matthysen et al. 2010). There are three main ethnic groups in Karamoja: the Jie, the Dodoth and the Karimojong, with the latter subdivided into ten sub-groups. The name Karimojong is also used for all the communities based in the Karamoja region, which is how we will use it in this article. The local language is Ngakarimojong originating from the Eastern Nilotic language group.

The climatic conditions of the region are arid or semi-arid where the highest average temperature ranges from $28^{\circ} \mathrm{C}$ to $32.5^{\circ} \mathrm{C}$ and the lowest from $15^{\circ} \mathrm{C}$ to $18^{\circ} \mathrm{C}$. Average annual rainfall in most of the Karamoja districts is $500-800 \mathrm{~mm}$ (DCA 2010; Mubiru 2010: 4). The rainy season is from March to September with a dry spell occurring in June and July (Levine 2010). The region is drier than the annual average rainfall figures would suggest, due to a high level of evaporation and loss of rainwater due to substantial water runoff to neighboring areas caused by the sloping topography. According to some current reports, climate change plays an important role, causing extreme weather and irregularity of rainfall patterns and rainy seasons as well as increasing temperature, bringing new challenges to local people (DCA 2010: viii, 1; Oxfam in Knaute 2009: 22). However, a strong irregularity of rainfall in spatial and temporal terms was a marked feature of the Karamoja climate by the 1940s and 1950s, as discussed by Neville DysonHudson in his detailed description of traditional Karimojong society in Karimojong politics (1966: 30-32). This irregularity and unpredictability of rainfall patterns exacerbated the fragility of local pastures and required flexible and knowledgeable day-by-day herding decisions.

As with many other pastoralist groups, the Karimojong were not completely nomadic, nor was livestock their only source of livelihood. They built permanent settlements called manyattas where everyone lived in the rainy season. Food cultivation, mostly of sorghum, was usually concentrated around the manyattas and was traditionally a women's domain (Knaute 2009b: 54; Onyang, O'Kasick 2007: 81). The men would leave the manyattas in the dry season to search for water and pasture for cattle and to create temporary settlements called kraals. The kraals served mainly as protection for livestock overnight. Although the combination of herding and cultivation spread risk, livestock were traditionally the main source of food security for the Karimojong, as cattle might survive in years when crops failed, and be slaughtered or exchanged for food if all else failed (Knaute 2009b: 19-20; Levine 2010; Spencer 1998: 20). In the past 
nutrition was secured by milk and blood, sorghum, vegetables, wild honey and fruit (Dyson-Hudson 1966: 38-40). Meat was eaten only during celebrations and religious events (Dyson-Hudson and Dyson-Hudson 1982).

Traditional authority in Karimojong society was vested in (male) elders. Decision-making and rituals took place in shrines called akirikets, sacred groves with political, social and religious functions (Stites et al. 2007). It was believed that gods live in the trees of the shrines and cutting trees, other vegetation, and hunting animals was strictly forbidden. Akirikets, or sacred, remain significant and are easily distinguished from profane places. The highest authority in decision-making concerning livestock management (the direction of livestock migration, pasture location and natural resource utilization) were the elders. The second highest level of authority were the kraal leaders who decided about daily migration routes and practical questions concerning water availability or protection of livestock against diseases (Nalule 2010: 8). Traditional pasture management entailed rapid mobility, different kinds of livestock grazing on different types of forage, differences between dry and rainy season grazing, and burning of certain areas. Elders and kraal leaders continually monitored water and pasture availability, and grazing patterns (Dyson-Hudson 1966: 33-80; Nalule 2010: 9-10).

In Karimojong society, cattle always held social and spiritual functions (Dyson-Hudson 1066: 94-103; Novelli 1989: 87). Pastoralism was not only a livelihood, but a lifestyle. The needs of cattle were often seen as more important than those of people. The Karimojong have many songs and poems about cattle (Knaute 2009b: 101-102; Novelli 1989) and rituals cannot take place and spiritual blessing cannot be received without the sacrifice of cattle. They are still an important symbol of individual status and play a significant role in Karimojong life, especially as regards marriage and upward social mobility. A wedding without gifts of cattle was not legitimized, and rights not transferred, hence young men sometimes resorted to cattle raiding (Dyson-Hudson 1966; Knaute 2009b; Novelli 1989; Spencer 1998; Stites et al. 2007: 5).

Many authors note that traditional pastoralism was well adapted to conditions in the Karamoja, as it mitigated the stresses that populations and ecosystems faced (DCA 2010; Dyson-Hudson and Dyson-Hudson 1982; Knaute 2009b; Levine 2010; Spencer 1998; ULA 2007). Knaute (2009a) states that pastoralism has had several positive impacts, contributing to ecosystem biodiversity through selective grazing, endozoochoric spread of seeds, burning, and manure additions.

While the semi-nomadic population lacked high rates of consumption or growth (Sahlins 1974: 54), Spencer (1998:28) shows that many East African pastoralist groups "had their sights set on growth": the goal of male family heads was to increase herd size, enabled by transfers through (polygynous) marriages for elders and their sons. But there were natural checks, like drought or epidemics. Spencer, following Tim Ingold calls this a "sawtooth pattern of growth and disaster" (1998: 41). Intermittent growth was not a threat to the environment (i.e. did not lead to overgrazing) as in the traditional mode it was balanced by long-term interests and restrictions (Spencer 1998: 229). As mentioned in the Introduction, one of the aims of this article was to learn more about traditional management of common pastures and to describe in more detail how it functioned in terms of safeguarding pasture fertility, drawing on the local knowledge of the Karimojong pastoralists themselves.

\section{Enclosure of the commons in Karamoja}

Over the last century, Karimojong society has had to face profound changes in its autonomy and access to grazing land. The first changes occurred at the time of British colonialization. From the European perspective, Karamoja was even less developed than the rest of the Uganda Protectorate and colonial officers faced the Karimojong $\square$ s reluctance to fall in with imposed and alien colonial hierarchies and rules (Barber 1962, Dyson-Hudson 1966:6-21). The rules nevertheless adversely affected access of the Karimojong to land: according to Oxfam (in Knaute 2009: 66) the Karimojong lost more than half of the pasture areas outside of the Karamoja region formerly assigned for the dry season especially due to the establishment of national borders. Since 1921 it has been forbidden to migrate with the herds outside the Karamoja region in 
the dry season (Dyson-Hudson in Knaute 2009: 66). Social conflicts began arising concurrently with the disturbance of traditional management systems (Pulkol in Knaute 2009: 59) and former self-sufficiency was disrupted. Migration outside of the Karamoja region was prohibited by colonial rulers and so was entry into Karamoja without a special permission (Cisternino in Knaute 2009: 59). Even though policies of economic and social development managed by western experts advocating change from a mobile pastoral lifestyle to a sedentary agricultural lifestyle were put in place, they were rather non-functional and the Karimojong continued to live in the traditional way (Barber 1962). Shortly before decolonization in 1962 the failure of colonial policies in Karamoja was admitted by the British administration and the Karimojong were left to their traditional lifestyles. However, crossing the borders remained forbidden (Barber 1962: 119, Novelli in Knaute 2009: 63) and no legal provisions were made to support the traditional lifestyle.

Two types of traditional land tenure prevailed in Karamoja. The first type was individual customary tenure usually comprising manyattas ${ }^{9}$ and manyatta gardens. However most of the land is under the second land tenure type which is communal customary tenure comprising pastures and shrines (Kamusiime et al. 2010). Communal as well as individual tenure had flexible borders which changed according to actual needs and individual property could become commons if authorized by elders (Kamusiime et al. 2010). The complexity and flexibility of Karimojong rights to land use as well as complex patterns of cattle ownership arrangements are discussed in Dyson-Hudson (1966). See also Robbins (2012: 201-202) for a more general discussion of traditional property institutions as complex bundles of rights.

Land ownership rights of the Karimojong were restricted first by the British and later by the Ugandan administration and their communal land rights were not recognized by the state before the 1995 Constitution of Uganda. The traditional lifestyle including land management in Karamoja thus took place outside of the legal framework of the British and later Ugandan government (Kamusiime et al. 2010). Currently communal land tenure is recognized by the state and people can obtain a certificate of communal land ownership based on the 1995 Constitution of the Republic of Uganda and the 1998 Land Act of Uganda (Kamusiime et al. 2010: 36, Bomuhangi at al. 2001: 5). However, the registration rates remain low due to illiteracy, low awareness and a complicated registration process. Moreover most of the registered land is in urban areas (Kamusiime et al. 2010: 38).

Access to land by local pastoralists was further eroded in the post-colonial period, when Karamoja started to be perceived as an area of high environmental value. About 94,6\% of Karamoja land had been designated as natural protected areas by 1965 for wildlife conservation (Kamusiime et al. 2010:1). ${ }^{10}$ Pastoralism was forbidden in the protected areas until 2002 when more than half of the previously protected areas were freed for use by the Karimojong. Traditional pastoral life thus progressed largely outside the legal framework of colonial and post-colonial administrations.

The various colonial and post-colonial interventions in Karamoja targeting access to grazing land described above resulted in increasing insecurity which correlated with the growing intensity of armed raids in the 1960s (Barber 1962: 124, Dyson-Hudson 1966:20). ${ }^{11}$ The intensity of the raids was linked with the rising efforts of the tribes to secure a sufficient amount of cattle and pasture. The same trend continued throughout the 1970s when the raids became even more violent and the number of small firearms increased (ULA 2007: 17). During the fall of the dictator Idi Amin in 1979 a large number of firearms from looted police barracks in Moroto town was acquired by the Karimojong. According to Stites et al. (2007: 55) twelve

\footnotetext{
${ }^{9}$ Manyattas are the traditional villages of the Karimojong.

${ }^{10}$ In the 1920s and 1930s Karamoja had been a prime hunting area in East Africa due to abundant wildlife such as zebras, buffalos, giraffes, elephants or antelopes. However, after 1950, a continuous decline in wildlife led to the establishment of game reserves and national parks (Kamusiime et al. 2010:1).

${ }^{11}$ Raids had traditionally been conducted with bows and arrows or spears, following traditional rules and the authority of the elders. The aim of the raids was to increase the number of cattle necessary for cattle exchange, territorial control of an area, restocking or improvement of the economic base of the Karimojong. The power of the elders decreased with young warriors strengthening their power as gun ownership became common and the nature of raids changed. Formerly killings and injuries during the raids had been rare (Novelli 1989; Nalule 2010) and livestock was not sold in the market for profit.
} 
thousand small firearms and a large amount of ammunition was stolen and circulated in Karamoja. In 1986 the Karimojong were considered fully armed (Vincent 1999: 118). The raids were a source of tension between the Karimojong and neighboring tribes which escalated at the beginning of the 1980s when severe drought and famine struck the Karamoja region. During this period the Karimojong raided most of the cattle of the neighboring tribes. The violence of the raids and the retrieval of weapons by the Karimojong increased until 2001 when the first government-led disarmament started. The amount of collected arms was relatively small and all tribes were not disarmed simultaneously, which led to a further increase in insecurity and violence in the region when the disarmed tribes were raided by the tribes that still had guns (Stites at al. 2007, Knaute 2009b). The second government-led disarmament started in 2006 when thousands of homes were burnt down, people suspected of holding guns were arrested and soldiers from the capital were transferred to Karamoja. It has been estimated that by March 2007 more than one hundred and fifty people had been killed during police interrogations. Human right abuses, the brutality of the Ugandan army and the high number of victims including women and children during the disarmament were strongly criticized (Stites et al. 2007, Mkutu 2008).

After the end of the second disarmament process the situation in the region calmed down and it is currently seen as relatively stable (DCA 2010: 9). As a result of the disarmament in 2006/2007, movement of pastoralists was seriously restricted. Cattle herds and herdsmen are now continuously accompanied by Ugandan soldiers who decide on the pattern and frequency of their migrations. Furthermore so-called protected kraals have been established. The soldiers are supposed to protect the herds as well as prevent raids and gun ownership by the Karimojong (Kamusiime et al. 2010: 40). Movement outside of the Karamoja region remains forbidden.

\section{Research context and methodology}

Research was conducted in Kotido district in July and August 2012 (see Figure 2). According to the 2002 census the population of Kotido district was 122,541, while in 2012 an approximate assessment of the population was 233,300 (UBOS 2012). The area covers 3,700 $\mathrm{km}^{2}$ (UN OCHA 2010). Kotido district is divided into six sub-counties: Kotido, Kotido Town Council, Nakapelimoru, Panyangara, Rengen and Kacheri. The district is inhabited by the Jie tribe. The whole Kotido district is an agro-pastoral area.

To answer the main research questions we looked at the relationship between traditional lifestyle, including pastoral management, and long-term sustainability of the pastoral ecosystems. The second step was identifying factors that had altered traditional commons management. The last step was to assess the connection between these factors and current environmental degradation.

We adopted a mixed methodology consisting of semi-structured individual interviews, focus group discussions and observation. There were three groups of respondents: group A consisted of elders and experts able to provide enough information about the past to be able to compare it with the present. Group B consisted of people living from new income-generating activities. Group $\mathrm{C}$ were herdsmen able to assess the current state of pasture management in the area. We identified a guiding set of questions and used them in the semi-structured interviews and focus group discussions, with questions differing for each group. The questions were open-ended and used as a framework for the interviews and focus group discussions. Sufficient space was given to the respondents to discuss a range of issues and raise their own concerns. Tables 1 and 2 show the number of interviews and focus group discussions conducted. 


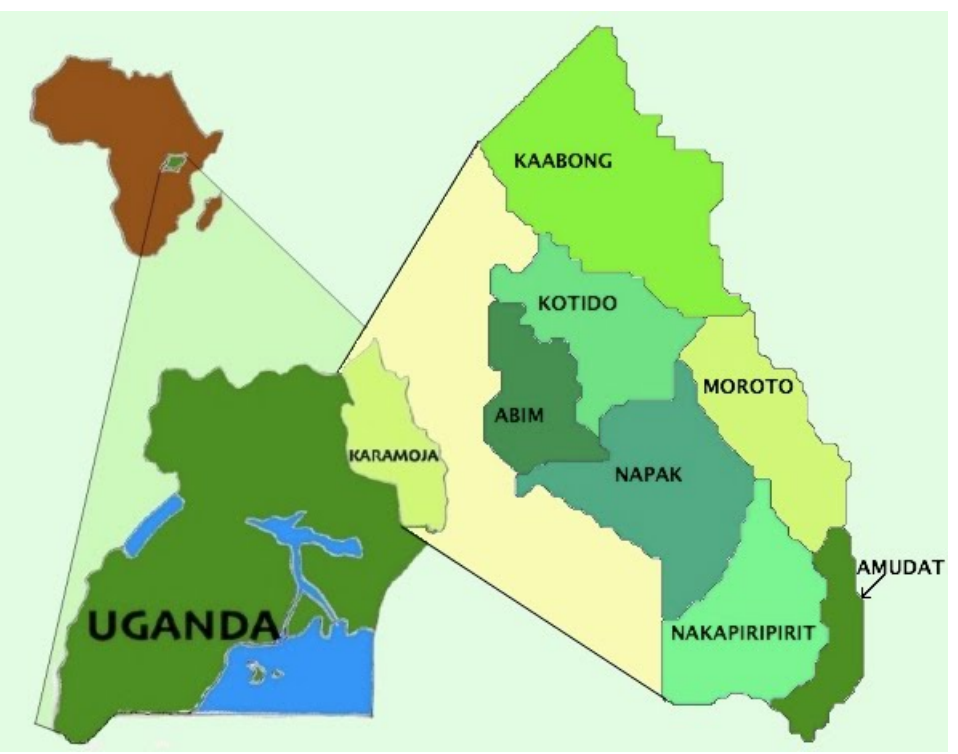

Figure 2: Karamoja region with districts. Source: Kotido Peace Initiative: About Karamoja, available from https://sites.google.com/site/kotidopeaceinitiative/about-karamo.

\begin{tabular}{|c|c|l|l|}
\hline $\begin{array}{c}\text { Interview } \\
\text { number }\end{array}$ & \multicolumn{1}{|c|}{$\begin{array}{c}\text { Number of } \\
\text { interviewees }\end{array}$} & \multicolumn{1}{|c|}{ Group } \\
\hline 1 & 1 & Woman living off charcoal sale & B \\
\hline 2 & 2 & Herdsmen & C \\
\hline 3 & 1 & $\begin{array}{l}\text { Catholic bishop living in Kotido since } \\
1979\end{array}$ & $\begin{array}{l}\text { A } \\
\text { interview }{ }^{12} \text { ) }\end{array}$ \\
\hline & 1 & $\begin{array}{l}\text { Program coordinator of international } \\
\text { NGO engaged in pastoralism supporting } \\
\text { projects }\end{array}$ & A (elite interview) \\
\hline 5 & 1 & District natural resource officer & A (elite interview) \\
\hline 6 & 1 & District local government officer & A (elite interview) \\
\hline 7 & 1 & Elder (male) & A \\
\hline 8 & 2 & Elders (couple) & A \\
\hline 9 & 1 & Elder (female) & A \\
\hline
\end{tabular}

Table 1: Interviews conducted.

\begin{tabular}{|c|c|c|c|}
\hline $\begin{array}{c}\text { Number of focus } \\
\text { groups }\end{array}$ & Number of persons in the focus group & Description & Group \\
\hline 1 & 8 & Elders & $\mathrm{A}$ \\
\hline 2 & 4 & Herdsmen & $\mathrm{C}$ \\
\hline 3 & $8-12$ & Brick layers & $\mathrm{B}$ \\
\hline
\end{tabular}

Table 2: Focus group discussions.

\footnotetext{
${ }^{12}$ For these interviews the "elite " interview approach as Gillham (2000: chap. 10) understands it was adopted.
} 


\section{Traditional approaches to safeguarding the environment}

In this section, we summarize the results of interviews pertaining to the first two questions (Was the traditional lifestyle of the Karimojong environmentally sustainable? Were traditional institutions in place to protect the environment?), Respondents pointed to traditional pastoral management approaches as well as to other environmental protection strategies.

\section{Traditional pastoral management}

The Karimojong were aware of the possible problems which overgrazing could cause in certain areas, as stated by one of the interviewees. The traditional method of pastoral nomadism plays an integral role in the relationship between traditional lifestyles and environmental protection. As the elders explained, migration in the dry season depended on swift movement according to the availability of water and pasture. Time spent grazing in one place depended on the amount of pasture and water available, and in the event that these became depleted, the herds would move on immediately. The kraal leaders would not allow the herd to stay one place longer than the ecosystem's perceived carrying capacity. Before every movement the kraal leader sent young herdsmen to scout out a new suitable location, which required enough water and pasture as well as an absence of livestock diseases. Every clan had a different traditional route that was followed every year.

Traditionally the herds had moved to the west across the borders of the Karamoja region to the neighboring regions of Teso and Acholi. Pastures in these areas were very important for the Karimojong in the dry season, due to the abundance of water and pasture during the period of scarcity in Karamoja. The availability of these pastures was a key element for the survival of the Karimojong in the dry season. According to the elders, the relationship between the Karimojong and their neighbors was good in the past, and agreement between the Teso or Acholi and Karimojong elders was validated by gifts from the Karimojong. Migration to these areas used to be preceded by a small advanced party who set the conditions of the Karimojongs' arrival and the pasture for their livestock.

Mobility was a way of coping with the harsh environment of Karamoja. The absence of the herds on the pastures in Karamoja during the dry season permitted regeneration and was proof of their knowledge of rangeland conservation. The absence of the herds was also a key element in areas called ngaperor. These places, specific for every clan, were used as reserve rangelands for a period when other pastures had been exploited; otherwise it was forbidden to graze them.

The traditional mobility of the Karimojong had two spatio-temporal levels. The first (macro) level were the long-distance dry-season migrations described above. At the second (micro) level, the Karimojong would change pasture every day in the area where they were currently settled. This micro-mobility rested on the decision of the kraal leader and would be in a different direction each day. As the herdsmen explained, the pastoralists were well aware of the reasons for everyday mobility from the kraal. The pasture would not be overgrazed and the water sources would not be over-exploited, because the pressure of the cattle was not too high since they would go every day to different grazing grounds. Continuous mobility on both levels made sure that the pastures were not overgrazed and the livestock had enough pasture and water to survive.

Other means of ensuring sufficient pasture for the cattle was pasture burning. Pastures were burnt in the dry season in order to allow new green grass for livestock to grow. There were traditional rules concerning the burning of pasture: after burning the area grazing was prohibited by the kraal leaders for a certain period and only when the grass had recovered sufficiently was grazing allowed once more. This method also served as a means of protecting the area against other tribes and ensuring sufficient pasture for periods when pastures would be scarce.

Furthermore, the impact of the Karimojong lifestyle on the environment was decreased due to the fact that every family had its own herds, built their own kraals and took their cattle out to pasture separately. In the case of wealthy families the livestock would be divided into several smaller kraals. Groups of livestock could join or separate, but every herd was independent. The small size of herds and of kraals was another mechanism for ensuring the sustainable use of natural resources, since the impact of herds on the environment was proportional to their size. 
A combination of the herds' mobility, the division of pastures according to dry and rainy seasons, the burning of certain areas and the existence of many small herds ensured not only the long-term survival of the Karimojong but also circumvented overgrazing and degradation of the ecosystems serving as pastures.

\section{Other traditional strategies and attitudes congruent with ecosystem sustainability}

Karimojong society developed other customary rules with an environmental dimension. Traditional shrines or sacred groves were one of the mechanisms to preserve resources. All respondents confirmed that it is strictly prohibited to fell trees, cut branches or hunt within the shrines. Disobeying these rules is interpreted as resistance against the elders, as well as the gods, and is punished by harsh sanctions, usually the sacrifice of a bull. Bulls have a high price in pastoralist society where cattle are killed only rarely. These traditional rules ensured the existence of important biodiversity refuges in the countryside with significant environmental value. As one of the respondents put it, the Karimojong were very experienced in siting the shrines, where the presence of water sources, big trees and important herbs which they wished to preserve were essential. Traditional rules concerning shrines are still in place and valid although some elders mentioned that Ugandan soldiers, who are outside of the traditional social control system, violate these customary laws and cut the trees in the shrines.

Tree-cutting was originally prohibited, and not only in the shrines. Karimojong respondents emphasized that custom also forbade cutting down large solitary trees, especially those in close proximity rivers. This rule, showing an implicit understanding of water cycles and the importance of trees for water retention, was expressed in religious terms by the respondents. However, this tree-felling ban is frequently disregarded today by many Karimojong. One of the respondents comments on some reasons for tree-felling:

Now people are felling trees as the only way of survival. In the past there were not so many trees cut down for fencing. (...). The fences were not huge as now, there weren't so many fence circles around the homes as it is now. The fences became bigger and there are more of them due to insecurity and intensified raiding. People have to earn a living somehow, so they lay bricks, make charcoal, and cut firewood. (...) This used not to be done before. People are desperate, most of them have no livestock or not enough, otherwise they would not do these things. (Program Officer, OXFAM)

Finally, in addition to these institutional arrangements, attitudes emerged during interviews with Karimojong respondents, indicating a certain humility with regard to non-human nature. One of the respondents summarized the Karimojong attitude: "I will take only what I need. If I need only ten sticks, I am going to take ten sticks, not eleven" (Catholic bishop). ${ }^{13}$

\section{Automatic weapons as a factor in lifestyle change}

As demonstrated in the previous section, traditional Karimojong livelihood procurement strategies were not inimical to environmental sustainability. This, however, is changing. Here we summarize interview answers to the questions: Which factors influenced these traditional institutions? What influence did each factor have on the lifestyle of the Karimojong? Or in other words: What were the main factors leading to lifestyle and livelihood changes over the last decades?

The main factor we uncovered in interviews was the acquisition of automatic weapons and the consequent intensification of armed raids in the 1970s. The role of guns in the region was to protect the herds, but they were also a means of acquiring more livestock. Interviewees emphasized the importance of guns for livestock protection, while their use for cattle raiding was not mentioned. ${ }^{14}$ The prerequisite for the

\footnotetext{
${ }^{13}$ Such an attitude would confirm Sahlins' (1974) contention that traditional societies spurn the accumulation of surplus and support Spencer's hypothesis that East African pastoralists' efforts to accumulate livestock were balanced by a view to long-term interests of the community (see close of section 3).

${ }^{14}$ Possibly because cattle rustling, traditionally a condoned, albeit predatory activity (Spencer 1998: 37-39), is morally condemned today.
} 
spread of armed raids was the diminishing power of elders who traditionally determined rules concerning cattle raids. In the past, the authority of the elders was so strong that without their permission the young men would not embark on a raid. However, with the arrival of firearms they gained relative political power and the elders were forced to condone raids they might not otherwise have permitted. Raids started becoming more violent and commercialized. ${ }^{15}$ In the late 1990s and early 2000s the security situation escalated to the point when cars would be ambushed and the passengers killed. Furthermore the cattle raided during the commercial raids were immediately taken out of the region and sold. The sale of cattle was a new trend appearing simultaneously with the appearance of automatic weapons and raids intensification, since in the past any raided cattle were used for marriages and for family food security.

Why did the Karimojong begin escalating raids and selling cattle in spite of traditional rules? The respondents were not asked this question directly, but interview responses indicated that the young warriors organizing most of the raids and selling cattle usually came from poor families, were orphans, or had lost most of their own family cattle in raids by other tribes. Similarly the large-scale raids on neighboring tribes' cattle corresponded with the severe drought and hunger in Karamoja in 1980/1981. The incidence of the raids, including their level of violence and the intensity, corresponded with an insufficient amount of cattle and the growing existential insecurity of the Karimojong. As many Karimojong did not have sufficient amount of cattle for their survival, they needed to have a financial income to obtain the staple foods and to cover new costs such as school fees or health care. With a developing monetary economy in Karamoja and a growing need for currency further pressure on conducting commercial raids emerged.

The increasing violence and insecurity in the region led to government interventions after 1986 . These were by no means a new development: attempts at Karimojong peacemaking had started in the 1960s with spear disarmament, and continued throughout the 1980s with confiscation of firearms. The government interventions from the mid-1980s can be divided into three approaches: firstly the prohibition of migration out of the Karamoja region, secondly the disarmament of the Karimojong and thirdly the establishment of protected kraals.

The prohibition of migration outside of the Karamoja region was confirmed by the elders, the herdsmen and the experts. The prohibition of herders' movements and control of the regional borders was enforced by bombing of cattle crossing borders by government helicopters in 2006. Currently the Karimojong are allowed to establish kraals only within the Karamoja territory and this has led to livestock concentration, causing forced overgrazing, the inability of ecosystems to recover, and consequent pasture degradation.

According to respondents, the disarmament process played a key role in the decrease of livestock numbers in Karamoja. It directly decreased cattle numbers through bombing and alleged thefts of livestock by Ugandan soldiers. The indirect impact of disarmament on livestock numbers was caused by the uneven nature of its implementation. This led to raids by armed tribes and to a loss of most of the cattle by the unarmed ones, including the Jie in Kotido where we conducted our research.

After disarmament, the tracking of the stolen cattle and their return to the original owners disrupted the traditional way of restocking after raids. Traditionally if a group was raided and lost all its cattle, it could raid again and get cattle back. The possibility of this type of restocking has nowadays been reduced, and poor families cannot step out of the poverty circle by raiding new cows. On one hand a vicious circle of escalating raids had been broken. On the other, a traditional means of restocking (raiding) had been precluded, leaving many locked into poverty in terms of cattle.

Furthermore the establishment of protected kraals disrupted traditional decision-making concerning cattle movement and kraal siting done by elders and kraal leaders. With the introduction of protected kraals the power was shifted to Ugandan armed forces. Free movement of pastoralists was prohibited, and currently they can move only in the presence of the Ugandan army. The shift of decision making caused four main types of changes in traditional pasture management:

\footnotetext{
${ }^{15}$ According to Grey et al. (2003: S3) the armed raids had been escalating since the 1970s with a serious impact on human population, in terms of mortality and morbidity. This corresponds with intensification of the acquisition of automatic weapons, as described earlier.
} 
1) Changes in time devoted to cattle pasture

2) The siting of the kraals

3) The character of mobility

4) Livestock numbers in the kraals

One of the research respondents claimed that the Karimojong must follow the timetable of the army. The livestock can go to pasture only after army meetings have finished, and must be back around 3 to 4 pm. In the past the livestock would go grazing very early in the morning and come back in the evening, which would allow them to feed sufficiently. This is no longer possible. Moreover with military supervision the herds follow the same route every day, as noted by the herdsmen. The daily rotation of herds from the kraals was discontinued with the establishment of the protected kraals. The result is not only insufficient pasture for livestock, but also overgrazing. Furthermore in the past the kraals were sited according to the needs of the herds. When a locality was exploited, the herds would be moved. Nowadays the protected kraals are sited according to the needs of soldiers, for example close to army barracks. Currently the army decides when the herds should move and as noted by herdsmen and elders, the herds remain too long in one place. According to the research respondents the army allows shifting locations only when it is too late, and livestock become weak or start dying off due to lack of pasture or water. In addition, livestock numbers in the protected kraals have increased significantly compared to the traditional ones. The concentration of large numbers of livestock has led to negative impacts on the environment such as soil compaction, vegetation loss and soil erosion as well as a spread of livestock diseases as noted by the research respondents (See also Nalule 2010: 12).

The Karimojong had a vast store of knowledge about their cattle's needs and about their environment due to their ecosystem-dependent lifestyle, and after living in the region for many generations. Army management has been a poor substitute, and not optimal for the livestock, humans or for the environment.

\section{New income-generating activities and their environmental impacts}

The previous section described changes in Karimojong livestock management, which do not allow communities to survive exclusively on traditional agro-pastoralism due to decreases in livestock numbers, driven by other contributing factors. ${ }^{16}$ What are the main means of survival among Karimojong today, if livestock numbers have decreased drastically? New income generating-activities have emerged over the last few decades. These include paid urban employment, sale of building sand and hardcore, firewood, and brick and charcoal production.

Respondents unanimously stated that they had adopted new income-generating activities because they lacked cattle. Brick-making and charcoal production are new trends in the region, and previous generations did not know of these activities. Firewood was sold in the past, but only very exceptionally. It seems that in the past pastoralism supplemented by subsistence agriculture were sufficient for survival, but this is no longer possible. Elders and one expert stated that town jobs are demeaning, and yet young people and even respected men in their prime are forced to accept petty jobs in urban areas as a precarious means of survival. This trend is entirely new, and these jobs would never have been accepted by the Karimojong in the past.

Deforestation seems to be increasing in Karamoja at least in part because of timber-cutting, especially for charcoal production (and perhaps for brick-making). This is from a respondent in the charcoal-makers' focus group:

The trees are finished. You finish in one place and then you continue going further for other wood (...). When I was small there were many big trees, now there are only small trees. The area is bare, there is little rain. When I was small the elders were stopping others from cutting

\footnotetext{
${ }^{16}$ As mentioned above, the current overstocking around protected kraal does not imply the overstocking of Karamoja region as a whole. Karamoja can be described as understocked, but with relative overstocking with regard to cattle distribution (overstocking in the areas of established protected kraals) (Nalule 2010: 6).
} 
the trees, they knew [the trees] were catching rainfall. All of these elders have died. Those who remain say you shouldn't cut the trees, but the famine is forcing [us] to cut the wood for charcoal. Cutting down the trees is better than stealing cows, there they can kill you. My parents didn't cut wood for charcoal.

In another interview, an elder corroborated the perception that the woody cover was eroding due to charcoalburning:

Those days there was lots of bush, you couldn't see a person from a distance, it was full of grass, trees. Now people cut lots of trees, trees are scattered. They cut them for charcoal, Akoro, hunger, made them learn the skill of burning charcoal. These days they cut trees illegally: you can be arrested by the government. But it is not punished by the elders, unless you cut wood in an Akiriket, a shrine.

The need for the Karimojong to use cash, e.g. for the purchase of clothes, medicines for people and livestock or payment of school fees further drives the new income generating activities and the consequent loss of tree cover. However most of the income is still spent on basic foodstuffs, because of the lack of livestock. The milk and blood of cattle, which constituted an important nutritional intake along with sorghum and vegetables, now need to be supplemented by food purchases. The new income generating activities are seen in a positive light by female respondents. As one of the female elders stated, the cash allows them to diversify their livelihoods and to become less dependent on livestock.

The changes described above have led to fewer livestock and to an inability to survive by traditional means, which has forced the Karimojong to search for new livelihood options. This has led to the eventual adoption of new income-generating activities including the sale of firewood, and brick and charcoal production. These activities are seen as factors behind contemporary environmental degradation, especially deforestation, in the Karamoja region.

\section{Discussion}

The results of our research indicate that the origins of the current environmental crisis in Karamoja can be traced back to the spread of automatic weapons in the 1980s. While cattle raiding was an established part of life, the influx of guns led to increased insecurity in the region, and provoked government intervention to improve security. But this led to decreased livestock numbers, and the Karimojong were forced to adopt new income generating activities to earn cash income to replace their traditional dependency on livestock.

A question remains: were weapons only the proximate cause of current environmental degradation? The movement of the Karimojong peoples had in reality been restricted since the colonial period. British colonial rulers did not consider community-managed land tenure to be a lawful type of ownership and as Karamoja became the property of the British Empire, colonial rules were arbitrary manipulated in the region (Muwonge 2009: 5). According to Muwonge (2009: 5), local people ceased to be considered land owners in 1903, and became tenants on the land of the British Crown. Dyson-Hudson (1966: 15-16) describes colonial methods of control of Karimojong migration, who were at times forbidden to move with their herds even in Uganda territory. ${ }^{17}$ The loss of land and resource access led to poverty, the instability of Karamoja, and increasing frequency of environmental distribution conflicts (Okoth-Ogendo in Muwonge 2009: 6). Access to

\footnotetext{
${ }^{17}$ He says: "Starting in 1921, movement to the dry-season grazing areas was prohibited, except with prior permission from the District Commissioner; and this was to be given only if official labour requirements had been met. Even when the requirements of forced labour ceased (...) official attempts to limit population movement continued (...) Thus, the Karimojong are forbidden to enter the eastern and south-western peripheral grazing lands of their territory without prior permission (...) But these areas provide the largest and most reliable dry-season supply of water and grass: so once again the Karimojong are led to oppose the restrictions in principle and circumvent them in practice" Dyson-Hudson (1966: 15-16).
} 
land - that is to say, pasture and water - was crucial in these conflicts, which continued until the end of the $20^{\text {th }}$ century.

Following Guha and Martinez-Alier (2000:12) and Gadgil and Guha (1995), the Karimojong are one of the many examples of ecosystem people, for whom environmental sustainability was essential to their survival. While the Karimojong were not technically forced off their land, and thus cannot be seen as environmental refugees in a narrow sense, their productive base and knowledge capital have been eroded, pushing them into the monetized economy. While this was not seen as negative by some of our female Karimojong respondents, perhaps given the strong patriarchy of traditional Karimojong society, open questions remain regarding the social, cultural and economic implications of this shift.

Quite apart from environmental distribution conflicts, the policies of the Ugandan government often emphasize agricultural sedentarization of the Karimojong in the name of improving the living standards of pastoralists and to promote environmental preservation (Human Rights Watch 2014: 30-31; ULA 2007). This factor was rarely mentioned in interviews, perhaps because of its sensitivity. Development policies often place implicit pressure on pastoralists and their mobile livelihood systems. National support to pastoralism in Uganda has been negligible; the focus is on agriculture (Nalule 2010; ULA 2007). As Levine (2010: 8) notes, the budget of the Karamoja Action Plan for Food Security (2009-2014) allocates less than US\$ two million to pastoral regions, but only one third of these funds (those earmarked for veterinary care) can be used by the ordinary inhabitants of Karamoja. The remaining two thirds are meant for the introduction of new livestock breeds, feed production or introduction of camel and ostrich farming, which will probably be valuable only for local elites. On the other hand, more than US\$ 21m was allocated for support to agriculture (Levine 2010: 8). The Karamoja Action Plan for Food Security does not support mobile pastoralism and also concentrates on agriculture. Moreover the national plans for the establishment of water infrastructure (Kisamba-Mugerwa 2001; Levine 2010: 4) as well as of education and health infrastructure (Knaute 2009a: 10) contribute to the sedentarization of pastoralists as the implicit prerequisite for regular access to these services is staying in one place.

Therefore, the causal chain of contemporary environmental degradation in Karamoja goes deeper than the influx and spread of automatic guns and the resulting violence. On the contrary, the dissemination of firearms is only one link within the complex causal nexus of the environmental problems that Karamoja is currently facing. The colonial past of Uganda should be a starting point for investigation given that the Karimojong have faced attempts to curtail their traditional lifestyle since the British colonization of Uganda. As a result of long-lasting power struggles, attempts were made to restrict the Karimojong and to subject them to colonial rule and later to a state power structure that saw pastoralism as outdated and primitive, echoing colonial value judgements and policies (Hudson-Dyson 1966). The resulting livelihood insecurity is causally linked to the rising insecurity and severity of conflicts in the region, and this is in turn linked to the current environmental crisis as well as to the insecure future of pastoral livelihood systems.

\section{Conclusions and suggestions for further research}

The aim of this article was to locate the source of current environmental degradation in the Karamoja region in Uganda, using a political ecology discourse framework, and the theoretical concept of the commons.

The traditional life of the Karimojong was once sustainable for the people as well as for the environment. Land tenure has a strong relationship with land use and livelihoods, and the predominant way of life among the Karimojong was as "ecosystem people." Pastures in Karamoja were managed as common property and some of the Karimojong traditional pastoral practices safeguarded the environment, refuting Hardin's "tragedy of the commons" hypothesis. When the traditional pastoral lifestyle was disrupted, the Karimojong way of life was negatively affected, as has occurred among other pastoral peoples as documented by Goldsmith et al. (1999), Lane (1994) or Squires and Youlin (2009).

The immediate factors of the disruption revealed by our study were the influx of firearms and increased cattle raiding, together with worsening security in the region, followed by disarmament, strict prohibition and control of Karimojong movements outside of the region, and the establishment of protected kraals leading to sedentarization pressures. All of these factors led to reduced cattle herds in Karamoja. 
Considering the fact that the Karimojong were dependent on their livestock, this had a significant direct impact on their lives, and arguably an indirect impact on the environment in terms of deforestation due to adoption of new income generating activities demanding high volumes of firewood (especially brick-making and charcoal production), as well as soil erosion, compaction, vegetation loss and poorer water retention due to establishment of protected kraals and consequent erosion of traditional herd management methods.

Looking beyond such immediate factors, the Karimojong have become marginalized socially and economically through a long-drawn-out and complex process of curtailment of their traditional livelihood strategies and land ownership patterns, beginning during the British colonial era more than a century ago, and continuing into the present with policies and funding priorities now skewed towards sedentarization and agriculture. Although they tend to be blamed for the environmental decline of their region, this is a case of "blaming the victim." The Karimojong are aware of the destructive side of their current livelihood strategies, but cannot easily step out of them. Pushed by the factors described above and pulled by the advent of new needs into a more monetized economy, they are responding to the demands of an urbanizing and growing population to the detriment of their own long-term environmental security.

Our field research was not able to reveal the deeper causes of environmental degradation dating back to the colonial period. Despite the pioneering work of Dyson-Hudson (1966), further archival research would be useful, covering the impact of colonial politics in Karamoja. This might serve as a starting point for future studies concentrating in more detail on the diverse and complex factors which are contributing to changes in the Karimojong way of life, including multiple sedentarization pressures and population growth. Another interesting line of research might look at the persistent assumptions made that demean traditional pastoralism as primitive (despite work emphasizing its ecological appropriateness in semi-arid East African environments) and the reflection of these assumptions in attitudes and policies that further marginalize pastoralist practices.

\section{References}

Agrawal, A. 2002. Common resources and institutional sustainability. In Ostrom E., T. Dietz, N. Dolsak, P.C. Stern, S. Stonich and E.U. Weber (eds.). The drama of the commons. Washington DC: National Research Council. Pp. 41-85.

Barber, J.P. 1962. The Karamoja district of Uganda: a pastoral people under colonial rule. The Journal of African History 3(1): 111-124.

Bassett, T.J. and K.B. Zuéli. 2003. The Ivorian savanna: global narratives and local knowledge of environmental change. In Bassett, T.J and K.S. Zimmerer (eds.). Political ecology: an integrative approach to geography and environment-development studies. USA: The Guilford Press.

Binswanger, H. and K. Deininger. 1999. The evolution of the World Bank's land policy: principles, experience, and future challenges. The World Bank Research Observer 14(2): 247-276.

Bollier, D. 2010. This land is our land. Film. Media Education Production. Available from <http://www.mediaed.org/cgi-bin/commerce.cgi?preadd=action\&key=146 with registration.

Bomuhangi, A., C. Doss and R. Meinzen-Dick. 2011. Who owns the land? Perspectives from rural Ugandans and implications for land acquisitions. IFPRI Discussion Paper. Washington DC: IFPRI.

Conte, T.J. 2015. The effects of China's grassland contract policy on Mongolian herders' attitudes towards grassland management in Northeastern Inner Mongolia. Journal of Political Ecology 22:79-97

Daly, H.E, and J.C. Farley. 2004. Ecological economics: principles and applications. Washington: Island Press.

Dyson-Hudson, N. 1966. Karimojong politics. Oxford: Clarendon Press.

Dyson-Hudson, N. and R. 1982. The structure of East African herds and the future of East African herders. Development and Change 13: 213-238.

Mkutu, K. 2008. Disarmaent in Karamoja, Northern Uganda: is this a solution for localised violent inter and intra-communal conflict? The Round Table 97 (394): 99-120.

DCA. 2010. Climate change and adaptation strategies in the Karamoja sub region. Kampala: DanChurchAid. 
de Soto, H. 2001. The mystery of capital: why capitalism triumphs in the West and fails everywhere else. London: Black Swan.

Deb, D. 2009. Beyond developmentality: constructing inclusive freedom and sustainability. London: Earthscan.

Emwanu, T., O.P. Okwi, J.G. Hoogeveen and P. Patt. 2003. Where are the poor? Mapping patterns of wellbeing in Uganda. Kenya: Uganda Bureau of Statistics and the International Livestock Research Institute.

Feeny, D., F. Berkes, B. McCay and J.M. Acheson. 1990. The tragedy of the commons: twenty-two years later. Human Ecology 18(1): 1-19.

Gadgil, M. and R. Guha. 1995. Ecology and equity: the use and abuse of nature in contemporary India. London: Routledge.

Gendron, C. 2012. Embracing the socially constructed dimensions of the economic system. In Cangiani, M. (ed.). Alternative approaches to development. Padova: Cleup. Pp. 67-84.

Gillham, B. 2010. The research interview. London: Continuum.

Goldsmith, E., N. Hildyard, P. Bunyard and P. McCully (eds.). 1992. Whose common future. The Ecologist 22 (4): 121-211.

Gray, S., M. Sundal, B. Wiebusch, M.A. Little, P.W. Leslie and I.L. Pike. 2003. Cattle raiding, cultural survival, and adaptability of East African pastoralists. Current Anthropology 44 (S5): S3-S30.

Guha, R. and J. Martinez-Alier. 2000. Varieties of environmentalism: essays North and South. London: Earthscan.

Harvey, D. 2007. A brief history of neoliberalism. Oxford: Oxford University Press.

Huang, J, Y. Bai and Y. Jiang. 2009. Case study 3: Xilingol grassland, Inner Mongolia. In Squires, V.R., L. Xinshi, L. Qi, W. Tao, Y. Wang and Y. Youlin (eds.). Rangeland degradation and recovery in China's pastoral lands. UK: CABI. Pp. 120-135.

Human Rights Watch. 2014. How can we survive here? The impact of mining on human rights in Karamoja, Uganda. USA: Human Rights Watch. Summary

Jacobs, M. 1991. The green economy: environment, sustainable development and the politics of the future. London: Pluto Press.

Kamusiime, H., E. Nsamba-Gayiiya and M.A. Rugadya. 2010. Tenure in mystery: status of land under wildlife, forestry and mining concessions in Karamoja region, Uganda. Uganda: Associates Research Uganda.

KFSCS Team. 2010. Reducing insecurity through self reliance. IOM International Organization for Migration.

Knaute, D. 2009a. Rethinking sustainability in pastoralist areas of East Africa. In Knaute, D. and S. Kagan (eds.). Sustainability in Karamoja? Rethinking the terms of global sustainability in a crisis region of Africa. Köln: Rüdiger Köppe Verlag. Pp. 1-15.

Knaute, D. 2009b. Literature review on Karamoja (Period 1943-2008). In Knaute, D. and S. Kagan (eds.). Sustainability in Karamoja? Rethinking the terms of global sustainability in a crisis region of Africa. Köln: Rüdiger Köppe Verlag. Pp. 19-142.

Lane, C. 1994. Pastures lost: alienation of Barabaig land in the context of land policy and legislation in Tanzania. Nomadic Peoples (34/35): 81-94.

Levine, S. 2010. What to do about Karamoja? Why pastoralism is not the problem but the solution. Food security analysis of Karamoja. Rome: FAO and ECHO.

MAAIF. 2010a. MAAIF statistical abstract 2010. Kampala: Ministry of Agriculture, Animal Industry and Fisheries, Republic of Uganda.

MAAIF. 2010b. Agriculture for food and income security. Agricultural sector development strategy and investment plan 2010/11-2014/15. Kampala: Ministry of Agriculture, Animal Industry and Fisheries, Republic of Uganda. 
Marshall, G.R. 2005. Economics for collaborative environmental management: renegotiating the commons. London: Earthscan.

Matthysen, K., S. Finardi, B. Johnson-Thomas and P. Danssaert. 2010. The Karamoja cluster of Eastern Africa: arms transfers and their repercussions on communal security perceptions. Chicago: IPIS.

Mkutu, K. 2008. Disarmament in Karamoja, Northern Uganda: is this a solution for localised violent inter and intra-communal conflict? The Round Table 97(394): 99-120.

Mubiru, D.N. 2010. Climate change and adaptation options in Karamoja. Rome: UN FAO, ECHO.

Muwonge, M.J. 2009. Promoting human security and peace in the pastoral Karimojong communities in Uganda: systems and strategies to mitigate land conflicts. Africa Peace and Conflict Journal 2 (2): 115.

Nalule, S.A. 2010. Social management of rangelands and settlement in Karamoja [online]. Rome: FAO, ECHO.

Nampindo, S., G.P. Phillipps and A. Plumptre. 2005. The impact of conflict in Northern Uganda on the environment and natural resource management. Washington DC: USAID and Wildlife Conservation Society.

Onyang, S and J. O'Kasick. 2007. Karamoja: Uganda's land of warrior nomads. Switzerland: Little Wolf Press.

Ostrom, E., R. Gardner and J. Walker. 2006. Rules, games and common-pool resources. Ann Arbor: University of Michigan Press.

Rahnema, M. 1998a. Introduction. In Rahnema, M. and V. Bawtree (eds.). The post-development reader. London: Zed. Pp. ix-xix.

Rahnema, M. 1998b. Towards post-development: searching for signposts, a new language and new paradigms. In Rahnema, M. and V. Bawtree (eds.). The post-development reader. London: Zed. Pp. 377-403.

Robbins, P. 2012. Political ecology: a critical introduction. Chichester, UK: Wiley.

Sahlins, M. 1974. Stone Age economics. London: Routledge

Scott, C. 2004: Conflicting discourses of property, governance and development in the indigenous North. In Blaser, M., H.A. Feit and G. McRae (eds.). In the way of development. London: Zed. Pp. 267 - 312

Spencer, P. 1998. The pastoral continuum: the marginalisation of tradition in East Africa. Oxford: Clarendon Press.

Stites, E., D. Akabwai, D. Mazurana and P. Ateyo. 2007. Angering Akuju: survival and suffering in Karamoja. Boston: Feinstein International Center, Tufts University.

Squires, V.R. and Y. Youlin. 2009. Historical degradation episodes in China: socio-economic forces and their interaction with rangeland grazing systems since the 1950s. In Squires, V.R., L. Xinshi, L. Qi, W. Tao, Y. Wang and Y. Youlin (eds.). Rangeland degradation and recovery in China's pastoral lands. UK: CABI. Pp. 15-29.

UBOS. 2012. 2012 Statistical abstract. Kampala: Uganda Bureau of Statistics.

ULA. 2007. Indigenous pastoral communities and the PEAP. Uganda: Uganda Land Alliance.

UN OCHA. 2010. Kotido district: basic services accessibility atlas. Uganda: UN OCHA. Current

Vincent, J. 1999. War in Uganda: North and South. In Reyna, S.P. and R.E. Downs (eds.). Deadly developments: capitalism, states and war. London: Routledge. Pp. 104-130.

WFP. 2016. Uganda. UN World Food Programme.

Zografos, C. and R.B. Howarth. 2010. Deliberative ecological economics for sustainability governance. Sustainability (2): 3399-3417. 